\title{
Strategic Innovation, Know ledge Sharing and Policy Innovation Factors In E-Government in Developing Countries: The Case of Tanzania
}

\author{
Emmanuel Constantine Lupilya* and Park J. Hun**
}

\begin{abstract}
The existing gap from strategic innovation in e-government knowledge creation has affected the effort to timely develop e-government policy in Tanzania. This paper is an attempt to describe multiple innovations outside the Tanzania that involve developing country collaboration, institutional innovation and resources and their linkages to national e-government-think tank. The central argument of this paper is to find factors for enhancing the development of national e-government policy innovation outside Tanzania. We developed national e-government policy framework to orchestrate local innovation and forge ahead of the e-government policy innovation. To do so, we developed and administered a set of the questionnaire from government and private institutions, entrepreneurship and social network group. Data collections were conducted from July 15 to September 20, 2015. The exploratory factor analysis using SPSS version 22 was employed to analyze data for strategic innovation, knowledge sharing, and e-government policy innovation. Four critical factors were identified as the key driver to the success of national e-government policy innovation: Coordinate knowledge sharing on e-government policies in the nation and international institutions; empower and coordinate e-government-think tank forum locally and nationally; create a technoculture society at local and national level; and Support e-government research alliance \& engagement respectively.
\end{abstract}

* Emmanuel Constantine Lupilya is a government official working in the Office of the President of Tanzania. He holds a Bachelor's Degree in Business Administration, a Master's of Science in Information Technology obtained from Finland, a Master's Degree in e-government and e-policy from Seoul, Korea. He is currently a Doctoral Candidate in the Graduate School of Public Administration at Seoul National University. His research interests include e-government, e-government policy, public policy, technology inequality, and e-government transformation in developing countries. E-mail: elupilya@gmail.com.

** Professor, Ph.D. in Business Administration (University of Minnesota). Research Interest: Information Management (Administrative Information Management, Business Information Management), Quantitative Analysis, Information Policy, E-Government, Research Methods for Public Administration and Policy. dearpark@snu.ac.kr.

Manuscript received October 12, 2015; out for review October 20, 2015; review completed November 24, 2015; accepted December 10, 2015.

The Korean Journal of Policy Studies, Vol. 30, No. 3 (2015), pp. 91-123.

(C) 2015 by the GSPA, Seoul National University 
In additional, three developing countries were used as a reference model to support these findings. Our conclusion shows how national e-government-think tank and research alliance can become a strategic innovation in e-government towards coordinating knowledge sharing within private and government institutions. This can represent as "valuable and intellectual assets" for government institutions' stability and change towards national e-government policy innovation process.

Keywords: E-Government Policy, Monocropping, Innovation, Knowledge Creation / sharing, Strategy Innovation, Institutional Capability, Knowledge Crisis

\section{INTRODUCTION}

The existing gap between the strategic innovation and the e-government knowledge creation has affected the effort to timely develop e-government policy in Tanzania. Government institutions also continue to lag behind the clock for the e-government knowledge creation underpinning institution's stability and change. Any stability and change in any institutions are associated with innovation that is linked to knowledge creation. For instance, the introduction of a new technology and the e-government (Song, 2006; Heeks, 2006a; Rabaiah \& Vandijck, 2009) are part of the innovation. Recently, government institutions have been focusing on developing a sound e-government policy rather than investing in e-government knowledge creation. In order to create a sound e-government policy innovation capability, the government institutions should embrace on e-government knowledge creation as a crucial and fundamental base for innovations (Nonaka, 1991; Nonaka \& Takeuchi, 1995; Song, 2002, 2006; Heeks, 2006a).

However, studies on knowledge and innovation have pointed out that for effective e-government knowledge creation, the government institutions should invest towards guiding individual knowledge creation capability rather than the adoption and imitation of e-government policy development approaches (Nonaka, 1991; Nonaka \& Takeuchi, 1995). The challenges are that external forces (Developed countries) encourage these institutions not to re-invent the wheel, but rather adopt the e-government policy metaphors which essentially leads to "e-government policy Monocropping" from developed countries (Grant, 2002; Cabrera \& Cabrera, 2005; Heeks, 2006a; Thandika, 2009).

A thorough investigation of a failure of e-government policy development shows that developing countries face a number of limited resources (Heeks, 2000, 2002, 
2003; Ndou, 2004; Thandika, 2009). This resource includes financial limitations, bad governance structure, poor institutional setup, weak leadership and self-enlighten to national projects as pointed by Earl (2001); Babu et al., (2007c) and Garavelli et al. (2004). This study argues that limited resources are significantly associated with institutional knowledge and innovation, creation (Bollinger \& Smith, 2001; Kotabe et al., 2007). Government institutions lack the intricacies of the localized e-government knowledge and strategic innovation to impact the e-government policy innovation development process (Grant, 2002; Cabrera \& Cabrera, 2005; Heeks, 2006a; Thandika, 2009). Notwithstanding the fact that, the failure of government institutions to collaborate with developing countries (Kenya, Rwanda, and South Africa) had shadowed and weaken the institutional knowledge and strategic innovation in e-government policy development (Nonaka, 1991; Nonaka \& Takeuchi, 1995; Bollinger \& Smith, 2001;). Similarly, a lesson from other developing countries shows that enforcing best practice approach for adopting e-government policy for developing countries is a serious burden. This burden is not only to government and social welfare but also intimidating institutional strategic thinking towards knowledge and innovation in e-government policy development (Yeh et al., 2006; Kotabe et al., 2007).

Another challenge which is associated to intimidating the institutional knowledge and strategic innovation is the concept of "one size mostly fits all" (Arcot, et al., 2006). It is in this context that, due to the insufficient knowledge of information to encourage innovation in e-government policy development, copying and transplanting of policies from developed countries becomes a fashionable and, therefore, an obstacle. Nevertheless, prophesizing "knowledge creation" within developing countries would offer a new dimension of learning paradigm shift in today's government institutions (Bollinger \& Smith, 2001). This is worthwhile for the current study to conduct the analytical view of the e-government policy innovation in developing countries with a focus to Tanzania. The aim is to show how national e-government-think tank and research alliance can become a strategic innovation towards coordinating knowledge sharing within private and government institutions. This can represent as "valuable and intellectual assets" for government institutions' stability and change towards national e-government policy innovation process (Bollinger \& Smith, 2001).

To achieve such aim, we ask the question of what are the success factors for egovernment policy innovation? The answer to this question is crucial and timely important because it offers a cutting-age framework for future e-government policy innovation and knowledge creation. This is a key strategic innovation and knowledge sharing within the developing countries towards enhancing stability and change for government institutional survival in a long-term (Bollinger \& Smith, 2001).

The main objectives of this study, however, are to 1) understands factors that 
contribute to the success of the e-government policy innovation development. 2) To suggest the framework for e-government knowledge necessary for the e-government policy innovation by integrating different levels of knowledge and strategic innovations from developing countries. The rest of the paper is organized as follows: section two is the theoretical background of the e-government knowledge creation, e-governmentthink tank, techno-cultural society, and e-government research alliance and engagement. Section three is the methodological part, which analyzes and discusses issues using the exploratory factor analysis. Section four provides analytical solutions towards egovernment policy innovation development framework as the cornerstone of enhancing integration of different innovation and creativity. Section five discusses the implication and rounding off the concluding remarks.

\section{THEORETICAL BACKGROUND}

\section{E-Government Knowledge Concept}

E-government intends to improve the online interaction between governments and citizens through the provision of better public services (Heeks, 1999, 2000, 2006, 2008). However, the evolution of e-government technology services from the internet to more transactions and integrated application puts much pressure to the government (Fountain, 2001; Heeks, 2006, 2008; Ndou, 2004). These pressures cannot be controlled, protected and managed in the absence of collaboration in e-government innovation policy. Developing countries (Rwanda, Kenya, and South Africa) are good examples in Africa that have acquired ICT policies and e-government strategies. These countries do share a similar culture, values, and norms of the family, society to the national level. We ignore several ambiguities within the qualities mentioned and strictly consider knowledge and innovation creation as the fundamental qualities that add value to the study under investigation.

In the study of Grantt (1991, 1996, 1996a, 1996b, and 2002) was interested in observing how organizational capability can be realized by integrating the different specific knowledge that explains organizational competitive advantage. The result of his study was focused on resource innovation that comes from "knowledge" as a component which resides in the mind of the individual. He pointed out that integrating (within the developing countries) this specific knowledge together really explains the government, institutional knowledge, and capability towards developing e-government policy innovatively (Cabrera \& Cabrera, 2005; Chen \& Huang, 2009).

While in Nonaka (1994) who has been widely referenced in the IS research field, 
defined knowledge from the point of socialization, combination, internalization, and externalization. Whereas in Polanyi's paper, he viewed Knowledge from a tacit angle as "informal knowledge that is embedded in the mental process and is obtained through experiences and work practices" while explicit knowledge is formal, systematic and can be codified into records such as databases and library" (cited in Nonaka, 1994). Davenport and Prusak (1998), they define knowledge sharing as an interrelated process acquiring from exchanging of knowledge between individuals or in a form of a group. In this study, we use Nonaka definition of "knowledge" interchangeably with Davenport and Prusak according to the contingency that defines the significant context of the current theme of knowledge sharing.

\section{Institutional E-Government Knowledge}

The focus under this factor is on the Institutions. Institutions, as used in this study, can be defined in the context of the structures or entities or organization which is by nature holds some assets, locations, infrastructures etc. (Skyrme, 2002). Institutions are therefore responsible for managing, collecting, and promoting the e-government knowledge. These institutions are private sectors, social network groups, government institutions (Ministries, Departments, \& Agencies) which in this study are referred to as key stakeholders. The importance of these institutions is to develop and promote egovernment knowledge through the integration of multiple experiences. This multiple experience involves the combination of e-government experiences, techno-know-how, IT concepts, Technological facts that reside within groups or people. So, institutions transmit e-government knowledge through sharing of memories pointing to the advancement of e-government or technology (Kotabe et al., 2007; Leiponen \& Helfat, 2011). According to TFPL (1999) argued that "for organizations to compete effectively in the knowledge economy, they need to change their values and establish a new focus on creating and using intellectual assets." The success of government institutions in developing the e-government policy innovatively depends on each other's knowledge. For instance, it depends on the ability to share the information, knowledge across institutions and treat these as intellectual assets for its survival.

The e-government as an institutional knowledge can become an important resource for all government institutions in terms of supporting the development of an overall national policy of e-government (Kotabe et al., 2007; Leiponen \& Helfat, 2011). Because of its urgency, institutional knowledge creation can only happen outside its boundary and thus may modify the internal structure and arrangement (Nonaka, 1994; Fountain, 2001; Grant, 1996a, 1996b, 2002; Zacka et al., 2009). This change is fundamental for government institution's stability to ensure performative aspects of knowl- 
edge sharing are carried forward within its framework setting and structures.

The fundamental responsibility of the government institutions is to understand the change in terms of their knowledge, attitudes, culture and values and align them into the knowledge repository for sharing routine (Nonaka, 1994; Grant, 1991, 2002; Zacka et al., 2009; Donate \& Guadamillas, 2010). For e-government knowledge point of view, it tends to impact positively to the e-government-think tanks, techno-cultural society, and e-government research alliance and engagement (see Figure 1). Such approach explains that institutions that are governing the e-government knowledge become powerful engine and that can affect other institutional branches during the absorption and development stages. This effect can be mitigated by investing heavily on setting up a strong base of institutions that will deliver appropriate e-government knowledge (Kogut \& Zander, 1992, 1993; Grant, 1996; Zack et al., 2009). From Nonaka (1994) perspectives, provides a significant context of knowledge that can be represented from socialization, combination, internalization, and externalization. In their perspective, government institutions can only acquire innovation through integrating the different specific knowledge that explains government institutions competitive advantage (Grantt, 1996a, 19996b, 1996; Kotabe et al., 2007; Leiponen \& Helfat, 2011). For stability and competitive institutions suggests that it should search innovation and knowledge outside its boundary to promote e-government knowledge. Such linkages can intensify the transporting vessels as the roadmap towards the diffusion of knowledge and innovation, pointing to other institutional branches (see Figure 1).

\section{National E-government-Think Tank}

The term national e-government-think Tank as used in this study refers to the established group of experts / professionals by law or authority whose aim is to serves as e-government-think tank. This specialized group has an ability to provide a substantial combination of advice, opinions, suggestions, visions, strategies, ideas, focusing on specific e-government strands or challenges. This involves the expertise in e-government / IT; technical personnel in e-government / IT; public policy analysts; economist specialists; National intelligence agency (NIS) experts; telecom agency; telecom architecture analysts, cyber security experts, etc. Despite the effort of government institutions to form national ICT think tank, there are still challenges in managing and integrating these knowledges and innovations process (Hargadon, 1998; Leiponen, 2011). The advancement of technology has disrupted many of the efforts of government institutions to hold firm the competency of their institutions. A new dimension of holding firmly the institutional competency is to institutionalize e-government-think tank (Bierly \& Daly, 2007; Lin et al., 2010). The process might be tedious, but worth 
doing it, for instance, recruiting smart young guys around the country starting from rural areas and moving toward urban areas. While empowering the techno-culture society, these smart young guys recruited should be centered in the process of establishing the e-government labs which will be located in each district, wards or regions (Donate \& Guadamillas, 2010; Lupilya, 2015). The central theme is to equip these young and smart guys with technological coaching, e-government training \& research, and technical IT development programs and e-government technical support skills (Song, 2002; Leiponen \& Helfat, 2011; Liebowitz, 2002). These would attract collaboration with developing country focusing on the e-government research alliance and engagement which are the backbone of e-government knowledge depository. However, in highly competitive technological trends with the dynamic challenges in e-government implementations (Hargadon, 1998; Kogut, et al., 1992; Leiponen, 2011), the e-government-think tank can visibly become an important device to mitigate e-government policy innovation challenges creatively.

In order to influence e-government policy innovation in an ever changing environment, government institutions must play an important role to enable e-government-think tank and other allies to create a culture of knowledge sharing and innovation as its internal routine of framework (Jantunen, 2005; Kotabe et al., 2007; Leiponen \& Helfat, 2011; Lupilya, 2015). According to Nonaka, \& Senoo, 1996, pointed out that effective integration of knowledge sharing among individual, institutions, and resources can enhance government institutional capability to address the challenges of fragmentation of policies (telecommunications and communication policies). In so doing, government institutions can mitigate critical challenges at a conceptual level in order to speed up the transformation process of the e-government national project. This can be done using their internal knowledge think-tank to develop a national e-government policy (Kotabe et al., 2007; Leiponen \& Helfat, 2011).

Davenport on Skyrme lamented on institutions that "It requires turning personal knowledge into corporate knowledge that can be widely shared throughout an organization and applied" for e-government knowledge ex ante (Skyrme, 2002). Equally important noted from George (1980), among other personality characters of the individual, he emphasizes on "Cognitive Style" which is also the base for this study. He lamented his claim that "every individual develops ways of storing, retrieving, evaluating and using information (Kogut, et al., 1992; Kumar et al., 2009). At the same time, the individual develops a set of beliefs about the environment, about the attributes of the other actors, and about the various presumed causal relationship that help the person to explain and predict. According to George (1980), he commented that "the fragmentation of policy at the conceptual level is being reinforced by the failure to develop an effective central coordinating mechanism for the organization 
and management of the policy process."

This is an important venue where government institutions can wreak havoc the knowledge from e-government-think tanks combine with the techno-cultural society, and e-government research alliance and engagement and apply into a practical e-government policy development process (Kotabe et al., 2007; Leiponen \& Helfat, 2011).

While challenges in e-government continue to grow more complex than before, threats from all over the world are obvious and are significantly associated with cognitive dimension (George, 1980). Moreover, challenges that can be observed within this dilemma are the questions of understanding what factors are necessary for government institutions to influence and coordinate the integration of e-government knowledge sharing (Kogut, et al., 1992; Leiponen, 2011). This knowledge sharing can happen within institutions such as e-government-think tanks, techno-cultural society, and e-government research alliance and engagement (Lin, 2008; Dalkir, 2011; Edna, 2011). It should as well be known that a mixture of belief, culture, Management style and values between them may continue to evolve, and impacts of the e-government policy development (Zelikow, 1994; Donate \& Guadamillas, 2010). The government, institutional may decide to become more proactive or reactive to a situation where e-government knowledge transformation process is devastating. On the other hand, government institutions should understand that challenges happen when there is no sufficient knowledge and innovation in e-government policy development (Liebowitz, 2002). The puzzle we can observe here is critical for government institution's knowledge and innovation capability.

\section{Techno-Culture Society}

The term techno-culture society as used in this study refers to as the group or social network or society which is transformed by technology and can influence the creative use of technology in a knowledge society. This virtual society originates from the social network groups; the social forum networks, the IT media group; the employees (private and public sector or institutions) who are transformed by technology. The idea of government institutions to set up techno-culture society within government and private institutions to coordinate the speed of the information society. This would essentially enhance knowledge to national e-government-think tank as its "back-up" knowledge device (Donate \& Guadamillas, 2010). E-government should be for citizens, stakeholders and other networked organizations interacting and share knowledge as one society (Kogut, et al., 1992; Leiponen, 2011). Practicing the culture of sharing information do promote the e-government knowledge that influence the techno-society. By forming ties with social-network, bloggers, and social media communication may 
bring about the information society (innovation) (Lee \& Choi, 2003; Heeks, 2002, 2003, 2006; Donate \& Guadamillas, 2010; Lupilya \& Jung, 2015). This innovation can be used to develop appropriate e-government policy for the future.

A recent study was done with knowledge sharing in government institutionsperspective in Malaysia, was the paper published in 2009 by Shiail \& Daudi, they looked knowledge sharing on an individual and society dimension and draw some major drivers for knowledge sharing among government institution's staff (Sohail \& Daudi, 2009). For instance, in their paper they found that working culture, staff attitudes, society involvement and motivation have a positive significance in enhancing knowledge sharing within individuals and create a knowledgeable techno-society. A similar study was done by Jain, Sandhu and Sidhu (2007), investigating barriers to knowledge sharing among staff and stakeholders - a case study of business schools in Klang balley, Malaysia. Their analysis revealed somewhat similar results in the study done by Jain et al, however, they emphasize on top management support to encourage staff to publish and disseminate knowledge via various methods (Sohail \& Daudi, 2007.).

One of the interesting studies was done on knowledge sharing in Academic Institution-A study of Multimedia Government institutions in Malaysia. They imagine that knowledge sharing as "natural activities" of government institutions can be practiced on various dimensions such as the number of seminars, conferences, and publication. This activity may provide eagerness of staff to share knowledge as what Kogut and Zander (1992, p. 391) described as "combinative capability." This combinative knowledge capability is similar to techno-culture society with an ability to exploit knowledge sharing. In their study, they found that incentive systems and personal expectation are the two key factors for knowledge sharing in any government institutions (Donate \& Guadamillas, 2010).

From techno-culture society point of view, first, the government institutions should consider a combinative capability as cogitated by Kogut \& Zander (1992); second, the government institutions should consider incentives systems, individual expectation, political desire and management support to encourage knowledge dissemination through publication, research and so forth (Zack et al., 2009); third, government institutions should consider reversing the order by creating knowledgeable and an informed local and national e-government society to champion the intricacies of national e-government policy challenges (Grant, 1996).

\section{E-Government Research Alliance and Engagement}

The alliance in this context involves the key stakeholders (such as the local and central government, educational institutions, Local IT industries or sectors, Healthy 
institutions, social network groups, private sectors, NGO's etc.) plus other members within developing countries such as the East African Union (EAU), International government organizations (IGO's), Southern African Developing Community (SADC). The prime goal of this alliance is to promote e-government research development for developing countries influenced by strong engagement between these key players mentioned above. The government institution should initiate the development of research towards e-government policy. It is evident that within government institutions in the area of technology and e-government dimension is dormant. This situation is critical for the government institution and, therefore, is alarming in an ever-changing e-government environment. However, the rate of transplanting e-government policy from developed to developing countries is still high and in ad hoc (Thandika, 2012). From the evidence, we can learn that the greatest number of e-government projects in the region have failed to achieve their objectives due to lack of information for egovernment, challenges due to different policies and strategies that are embedded in egovernment projects (Ndou., 2004; Heeks, 2006; 2008).

Very often than not, government institutions are becoming like a watchdog in the implementation of various projects funded by external donors or AID (Heeks, 2002, 2006; Ndou, 2004; Mutula \& Mosters, 2010). This suggests that it limit the ability of knowledge sharing on project implementation process and causing the development of e-government policy innovation resulting in a crisis. This is similar to Ioannis Lianos ${ }^{1}$ who observes that donors do share knowledge and innovation mirroring to their own country during implementation. Even if the government institutions foot ahead for e-government sharing without sufficient research and publication or engagement may create a room for innovation and creativity deadlock. The government institutions should prophesize on alliance and engaged in promoting sustainable knowledge creation and sharing an e-government policy innovation through research (Lee \& Choi, 2003; Ndou, 2004; Lin, 2008; Edna \& Tuvya, 2011; Mutula \& Mosters, 2010). The approach may explain e-government policy development as a dependent exercise for local or national that would excavate creativity and innovation (Metcalfe et al., 1998). So government institutions should provide substantive engagement support in research and alliance towards e-government to invent new techniques for developing e-government policy innovatively.

The external strategy of enhancing innovation and creativity, sharing through "best practice" has failed to explain the potential benefits of internal strategy development

1. Competition Law and Intellectual Property Rights: Is the Property Rights' Approach Right? John Bell \& Claire Kilpatrick (ed.), Chapter 8 in Cambridge Yearbook of European Legal Studies (Oxford: Hart Publishing, 2006), pp. 153-186. 
of e-government policy (Ndou, 2004; Mutula \& Mosters, 2010; Lupilya., 2015). This is similar to the concept of a universalistic [one size fits all] that tends to weaken innovation and knowledge creativity (Lee \& Choi, 2003; Lin, 2008; Edna \& Tuvya, 2011; Thandika, 2012). Government institutions should see that investment in developing excellent e-government research alliance and encourage engagement with another alias may shed light for institutional innovation capability and prosperity.

From a strategic innovation point of view, this is true in the sense that process for policy innovation requires external collaboration in terms of knowledge sharing outside their institutions boundary (Nonaka, 1994; Krogh \& Nonaka, 2000; Liebowitz, 2002; Jantunen, 2005; Lin, 2008; Kedia and Mukherjee, 2009;). Innovation and creativity are as equally important as assets in the government institutions intellectuals whose focus has been relied on e-government research alliance and engagement process (Nonaka, 1994; Krogh \& Nonaka, 2000; From this perspective, we conclude that e-government research alliance and engagement is more than strategic innovation assets for future government institution's competitiveness in e-government policy innovation.

\section{E-Government Policy Innovation}

The term innovation has been defined by Nonaka (1994); Lioyd-Reason et al. (2002); Bommert (2010); Sorensen and Torfing (2011) as a "formulation as well as the implementation and diffusion of new ideas" (Walker, 1969; Gray, 1973; Mintrom, 1997). One can observe that policy innovation reflects innovation in a form of engagement and connection of externalities (Walker, 1969; Gray, 1973; Mohr, 1969; LioydReason et al, 2002) in the process of forming up a new idea, debug them and transform towards a specific direction (Bommert, 2010; Sørensen \& Torfing, 2011). For policy innovation point of view, it tends to provide the general direction or vision to be achieved in a future through planning, designing, formulation and implementation (Sørensen \& Torfing, 2011). This definition is contrary to Walker (1969); and Gray (1973) who suggested that, innovation, happened when the new process / idea change is found to be working better from the old process / idea.

Several studies on policy innovation have been conducted in the field of public policy and political science (Walker, 1969; Gray, 1973; Rogers, 1983; Berry \& Berry's, 1990; Mintrom, 1997), however, the results of policy innovation pointing to the e-government transformation are inconclusive. The prime objective of the study is to analyze the key indicators necessary for policy innovation and how it can influence the development of e-government policy innovation. This e-government policy innovation would substantially accelerate the transformation of e-government concurrently with the speed of designing, implementing, and transformation (Berry \& Berry's, 1990; 
Mintrom, 1997; Mclendon et al., 2005). Building on the work of Walker (1969) and Gray (1973), the study suggests that key indicators (players) from government and private institutions (the decision-makers, public policy makers / designers from public and private institutions, politicians, local and central government) and the national egovernment-think tank (in Mintrom, 1997, uses term as "policy entrepreneurs" referring to as a group of people whose idea is to bring policy change through policy innovation), are considered to be the source of policy innovation (Mclendon et al., 2005; Babu et al., 2007c).

The work done by Berry and Berry's (1990) suggested that event history analysis (EHA) can be a catalyst to analyze this key indicator including the techno-culture society and the e-government research alliance \& engagement that influence the national e-government-think tank. In essence the policy can be the vessels to uplink the interaction between institutional e-government knowledge and the national e-government-think tank (according to Mintrom, 1997, referred to as a "policy entrepreneurs") that may significantly promote the development of policy innovation (Walker, 1969; Gray, 1973; Berry \& Berry's, 1990; Babu et al., 2007c). The policies such as the telecommunication policy, the IT policy, broadcasting policy and strategies, free of information policy, media policy, etc. can innovatively be analyzed in the context of EHA approach (developed by Berry and Berry's 1990) to create a sound and powerful e-government policy that correlated significantly with innovation (Wlaker, 1969; Gray, 1973; Mohr, 1969; Babu et al., 2007c).

In developing countries, the literature indicates that the key failure that leads to poor development of e-government policy innovatively is due to the persisting gap between internal and external indicators (key players) similarly suggested by Mohr, (1969); Berry and Berry's, (1990) (in terms of knowledge, experiences, expertise, and technical terms in the field of policymaking.) and the designing reality of the e-government policy. Secondly, are the institutional barriers and their rigidity to allow diffusion of innovative change within and without institutions (Walker, 1969; Mohr, 1969; Gray 1973; Mintrom, 1997). For instance, the failure to maximally utilize the national ICT broadband backbone infrastructure (NICTBB), failure to control telecommunication price-based incentives, failure to implement and transform e-government national-wide, dependency (on IT technical or expertise, infrastructure development, design and transformation of IT or e-government); institutional failure to embrace changes in the direction of e-government (ability to provide guidance on networking, online sharing, online protection, enforcement of laws and regulations, IT standards, internet priceincentives, subsidies over communication tools \& standards, accessibility and connectivity standard price, e-government standards, techno-culture standard, e-government R \& D, e-government-think tank, political and leadership will etc.). 
Similar to our model, institutional e-government knowledge which includes both internal and external players can directly interact with the techno-culture society and the e-government research alliance and engagement as key players to form the policy innovation process (Mohr, 1969; Rogers, 1983; Berry \& Berry's, 1999). Institutional e-government knowledge should empower national e-government-think tank that constantly interacts with internal and external key players in search of policy innovation development (Walker, 1969; Gray, 1973; Mohr, 1969; Rogers, 1983). The use of EHA (Berry \& Berry's, 1990) is suggestive to uncover elements associated with factors such as techno-culture society; e-government alliance and engagement while strengthening institutions such as the national e-government-think tank and institutions e-government knowledge.

For instance, Tanzanian e-government policy failure is influenced by the lack of egovernment knowledge and innovation towards designing and developing policies. This e-government policy should essentially be able to address issues like empowering citizen on e-government knowledge, governance structure, poor institutional setup, weak leadership, financial resources, technical infrastructure and so forth. This dilemma can be viewed within the e-government policy which were not designed to address issues of e-government innovation from different perspectives in a form of a new idea, expertise, systems development, strategic leadership etc. The end results have always rested on a significant failure to transform the e-government as well as to identify smart and knowledge personnel who are able to introduce new e-government policy innovation that might address all these challenges (Babu et al., 2007c). This e-government policy innovation may become a new instrument or tool for converging related policies into one and be used as the standard unit of measurement for e-government transformation process (Sørensen \& Torfing, 2011). The study highlight somehow similar challenges or problems faced by the rest of the developing countries in their struggle to develop e-government policy innovation.

For instance, Rwandan e-government policy development was faced with lots of challenges including the technical know-how, knowledge on e-government, leadership and political will, which are similar to the rest of developing countries. It turns out to be that, the key success factor for Rwandan e-government policy innovation lies on four factors combined in an internal and external determinants (Berry and Berry's, 1990; Mintrom, 1997; Mclendon et al., 2005) these four factors: Access to ICT's where they encouraged networked environment; Training and capacity building where they encourage on Technical talent pool at all levels; e-Gov and mGov Applications where they focus on public services, healthcare and agricultures and lastly is the policies and strategies where they focus on national eGov policies and strategies as well as strengthening e-Cultures (Rwandan e-Gov vision). ${ }^{3}$ 
The Kenyan case, they were faced with infrastructure development challenges, the willingness to go online for most of the public institutions, lack of governing bodies for the implementation of e-government policy, lack of knowledge and innovation towards e-government transformations which are similar to the work done by Walker (1969); Gray (1973) on internal and external players for policy innovation. Their success story lies on Technology access via techno-centers; the establishment of Kenya education network (KENET) this provides collaboration in terms of research and publications. It includes several areas such as health, agriculture, education ICT, engineering etc. this is a central feature of fueling innovation. The Digital Villages: this is established to diffuse the e-government or ICT knowledge at a local and national level. The KONZA Technology Park is another dimension of e-government program initiatives for the country. Mainly is to save as an ICT business center to fuel ICT or e-government knowledge creation and innovation (IST-Africa Research). ${ }^{3}$

While South Africa, the country was on turmoil from apartheid war, leadership instability, political unrest, and some economic challenges South Africa did not match with the earlier speed of e-government transformation. Very interesting is that, recently, the South African economic status is shooting very high, and the diffusion of innovation towards e-government policy, e-government transformation were given priority. Today's, the e-government transformation lies on the strong culture and beliefs, which helped them to initiate and developed e-government policy for ten years plan pointing to their culture slogan of putting people's first. In comparison with Mintrom, 1997 with Berry and Berry's (1990) the South African e-government policy innovation was developed for ten years plan. This is similar to Berry and Berry's (1990) approach of using EHA as the sources of policy innovation and development. To do so, the government created Presidential National Councils on ICT. Several initiatives followed including the establishment of government's Batho Pele National Gateway Project—which literally means putting people's first (Maumbe \& Owei, 2007). To sum-up, the e-government policy innovation approach is significantly correlated with empowering the e-government-think tank which is influenced by e-government research alliance as well as the techno-culture society.

2. http://www.eaigf.or.ke/files/2012_eGOV_Case-Study_Rwanda.pdf (accessed on August 15, 2015).

3. https://www.ist-africa.org/home/default.asp?page=doc-by-id\&docid=5181 (accessed on August 15, 2015). 


\section{The Research Framework}

We aim to develop the e-government policy innovation framework for the government institutions in Tanzania. The framework acts as a connecting dot for the implementation and transformation of the e-government policy innovation. Based on the four factors analyzed and identified, we build the said framework reflecting the collaboration between developing countries with a special focus in the contextual environment of Tanzania. Using the available opportunities, and capitalize on the key results on e-government challenges in Tanzania, we modified elements of the paper published recently by Lupilya, 2015. We presented four critical factors for successful e-government policy innovation: e-government knowledge; e-government-think Tank; technoculture society and e-government research alliance and engagement (see Figure 1 below).

The above Figure 1 presents two key institutions that can enact the e-government policy innovation: The institutional e-government knowledge and the National egovernment-think tank. The institutional e-government knowledge incorporates two fundamental institutional entities: The government institutions (Ministries, Departments, and Agencies) and the Private Sector Institutions. The fundamental principal of this institutions is to significantly influence the technoculture society and the e-government research alliance and engagement focusing to e-government policy, Furthermore, the institutional e-government knowledge can influence the creation of National e-govern-

Figure 1. The Proposed E-government Policy Innovation Framework for Government Institutions in Tanzania

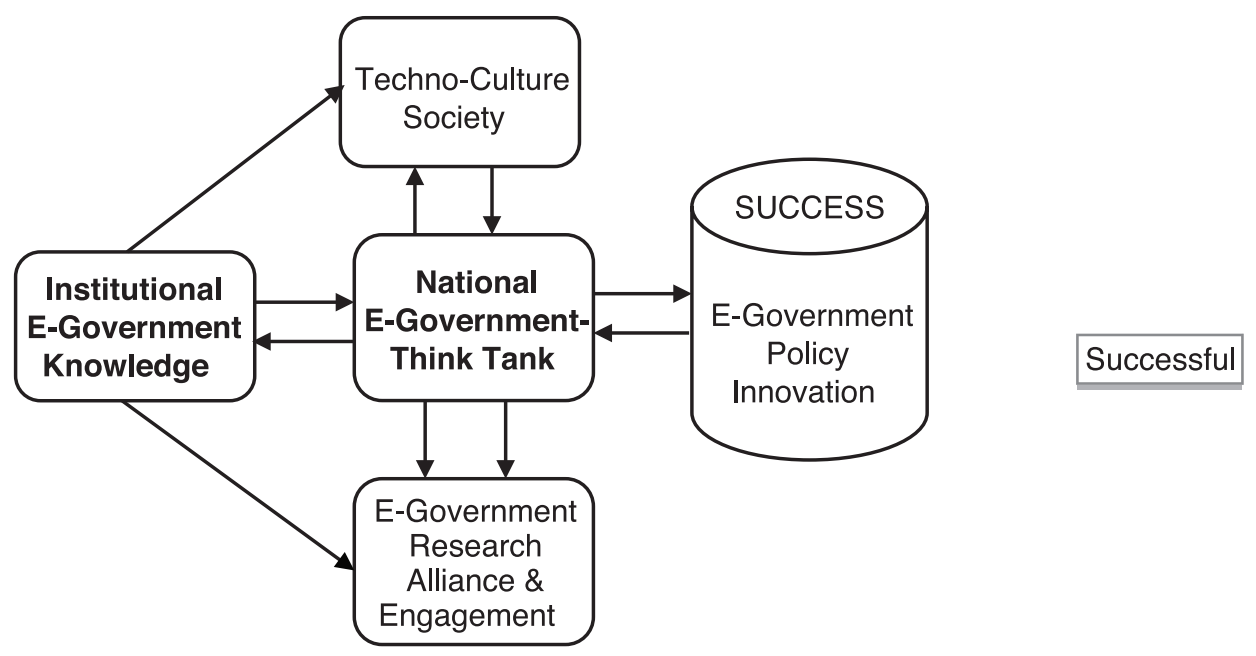


ment-think Tank as key institutions that enact the e-government policy innovation. The national e-government-think tank is linked between the techno-society cultures that provide information relevant to contextualized e-government combined with the engagement of e-government research alliance across borders. However, at the same times, it can impact the modification of technoculture society as well as the e-government research alliance and engagement in pursuits of the efficiency e-government policy development. For instance, during the development process of the e-government policy, the institutional e-government-think tank can re-arrange the structures and design e-government policy influenced by the technoculture society combined with the flow of adequate information from the e-government research alliance and engagement. This process can streamline necessary structures and entities aimed at enacting e-government policy innovation respectively. To sum-up, the framework reflects both private and government institutions as well as a socially networked group for the development of e-government policy which will contribute significantly to the social-economic perspective. From government institutions to the creation of an informed social network group and citizen may accelerate the cutting age of increasing the gain from the overall social-economic process lifecycle, efficiency and productivity at large.

The current study contribution is that, ignoring this e-government policy innovation framework might accelerate the institutional knowledge gap far from enacting effective and contextualized e-government policy for Tanzania. This framework is timely and crucial in assisting government institutions to screen and analyze parasites that might affect the development process of the e-government policy in Tanzania.

\section{METHODS AND ANALYSIS}

\section{Data and Method}

Tanzania was taken as a sample to represent developing countries. A sample size of 87 who responded out of one hundred and twelve respondents to the study was conducted based on e-government knowledge. This target group was randomly identified from government institutions, the private sector, social network group as well as entrepreneurship in Tanzania. These groups are knowledgeable about e-government as well as policy development process. The government institutions are composed with innovative personnel and knowledgeable staff on e-government as well as policy issues. Social network group, private institutions as well as entrepreneurship has received their education from technical / vocational training to university level and they represent as knowledgeable staff in the field of e-government and policy innovation development. 
We conducted a pre-test sample of 9 questionnaires out of 24 to see the validity reliability of our instruments and the understanding of the participants. The results were positive with a response rate of above $89 \%$. We modified several questions in the questionnaire which reflect some ambiguities. Some difficulty questions with mixed concepts were omitted from our questionnaire.

In Table 1 and Figure 2, shows the respondent's characteristic presentation. The table shows the total of 87 respondents of which 28 (32.2\%) were female and 59 $(67.8 \%)$ were male. The data show that about ages the $29(33.3 \%)$ respondents were less than 20 years, followed by respondents who at an average age of $>50$ were only $24(27.6 \%)$. However, $14(16.1 \%)$ respondents were found to be over 50 ages. In terms of working experience respondents analysis shows that for the length of services only $62(71.3 \%)$ respondents had a working experience of $>5$ years as opposed to the 14 $(16.1 \%)$ respondent who have working experience of 5 years. Figure 2 represents the histogram characteristics of the respondents in details. On average, our respondents were experienced and knowledgeable to the study in question according to our data and analysis. Our questionnaires were equally distributed to all participants and the response rate was encouraging as expected in our study.

Figure 2. Histogram Representation of the Characteristics of Respondents

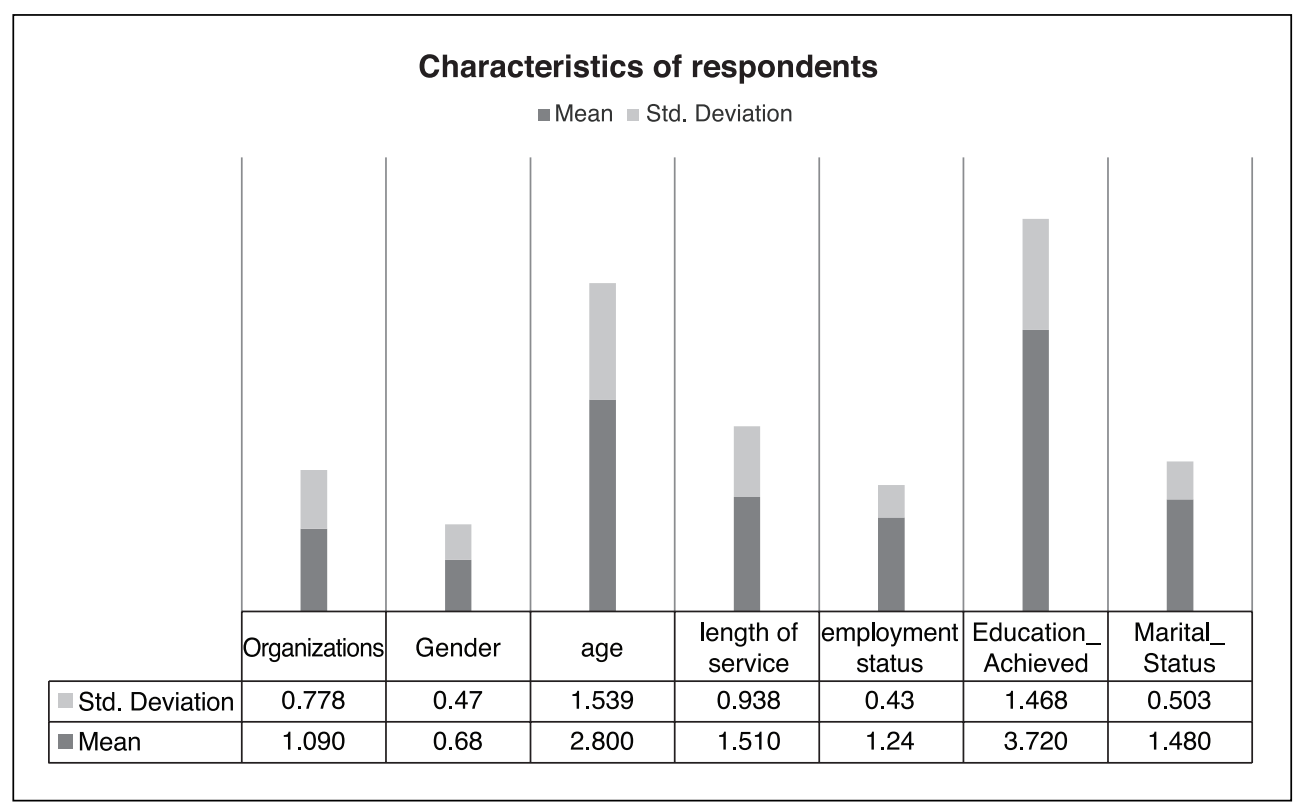


Table 1. Frequency Distribution for the Total Sample of the Population $(\mathrm{N}=112)$

\begin{tabular}{|c|c|c|}
\hline & Frequency & Percent \\
\hline \multicolumn{3}{|l|}{ Gender } \\
\hline Female & 28 & 32.2 \\
\hline Male & 59 & 67.8 \\
\hline \multicolumn{3}{|l|}{ Marital Status } \\
\hline Married & 45 & 51.7 \\
\hline Single & 42 & 48.3 \\
\hline \multicolumn{3}{|l|}{ Education Achieved } \\
\hline High School Level & 12 & 13.8 \\
\hline Vocational Training School & 12 & 13.8 \\
\hline Technical Colleges / School & 27 & 31.0 \\
\hline Universities Level & 36 & 41.4 \\
\hline \multicolumn{3}{|l|}{ Average Age of the Respondent } \\
\hline Under 20 & 29 & 33.3 \\
\hline $21-30$ & 11 & 12.6 \\
\hline $31-40$ & 9 & 10.3 \\
\hline $41-50$ & 24 & 27.6 \\
\hline Over 50 & 14 & 16.1 \\
\hline \multicolumn{3}{|l|}{ Length of Employment services } \\
\hline Under 5 Years & 62 & 71.3 \\
\hline 5 Years & 14 & 16.1 \\
\hline 10 Years & 3 & 3.4 \\
\hline Over 11 Years & 8 & 9.2 \\
\hline \multicolumn{3}{|l|}{ Employment Status } \\
\hline Permanent employment & 66 & 75.9 \\
\hline Casual employment & 21 & 24.1 \\
\hline \multicolumn{3}{|l|}{ Type of the Organization attached } \\
\hline Government Institutions & 27 & 31.0 \\
\hline Private Institutions & 45 & 51.7 \\
\hline Social Forums Institutions & 13 & 14.9 \\
\hline Educational Institutions & 1 & 1.1 \\
\hline Entrepreneurship & 1 & 1.1 \\
\hline
\end{tabular}


Only $8(9.2 \%)$ respondents were found to be well experienced worked over 11 years. Among of the respondents with employment status, only $66(75.9 \%)$ have an employment status as a permanent working staff whereas $21(24.1 \%)$ were casual labor. This group represents the majorities of casual labors who works casually and are paid upon their frequency appearance on duty. On average, the highest education level of the respondent indicates that $36(41.4 \%)$ have acquired a university degree level of education as compared to $12(13.8 \%)$ respondents who acquired the lowest level of education (high school-which is counted to have no professionalism). But only 27 $(31.0 \%)$ are the respondents who acquired a technical level of education. With regards to the organizations category, $45(51.7 \%)$ of respondents are working in a private institution, whereas only $13(14.9 \%)$ are working on social forums institutions. For government institutions, only $27(31.0 \%)$ respondents are employed and working as an ICT or IT specialist.

\section{Methods}

The study was conducted from Tanzania as one of the developing country using online mail survey. During data collection, a random online interview were conducted using social media communication such as Skype, Viber, and WhatsApp to minimize some bias and clarify on the respondent's information and answers (Lichtenthaler, 2009). The study developed a set of questionnaire and was somehow modified to best suit the topic of interest. This questionnaire was based on the previous studies conducted by Lupilya \& Jung, (2015); and Lupilya, (2015) using five-point Likert scale $($ Strong agree $=5$, Agree $=4$, undecided $=3$, Disagree $=2$, strongly Disagree $=1$ ) . However, we double checked the questionnaire and revised to suit the context of the study and were distributed to the participants. We asked the participants to complete all sections necessary for knowledge sharing and institutional innovation towards egovernment policy development. Most of the respondents delayed submitting their questionnaire on time due to the general election campaign, which is going on in Tanzania. We randomly selected participants who were involved in the study and make a follow-up using IP phone call (free online calls) for structured and non-structured interview depending on the circumstances. 


\section{RESULTS AND DISCUSSION}

\section{Research Instrument and Reliability}

We conducted the principal component factor analysis to examine whether there was the discriminant validity of our variables using the direct Oblimin rotation method. Five items were loaded: Coordinate knowledge sharing on e-government policies with the nation and international institutions; Empower and coordinate e-government-think tank forum locally and nationally; Create a techno-culture society at local and national level; Develop and maintain national information enterprise architecture; and Support e-government research alliance \& engagement respectively as indicated in Table 2. Based on the eigenvalues our total variance explained is $80.0 \%$ (Appendix 1) extracted out of 24 items. We dropped scale 4 (see Appendix 1 and Appendix 2) which was below the accepted level of 0.1 in order to increase the Alpha to 0.816 (Streiner \& Norman, 1995). So our results show that the Coefficient Alpha test is 0.816 that explains the reliability of our instruments as certified for further analysis. This is in consistency with the recommendation of above 0.7 Alpha the best significant level as provided by Bagozzi and Yi (1988), Nunnally and Bernstein (1994). The KaiserMeyer-Olkin Measure of Sampling Adequacy obtained were 0.773 which is above the recommended level (Appendix 2). The Bartlett's Test of Sphericity measure analysis was appropriate amounting to 2976.077. The strategic innovation, knowledge sharing and e-government policy innovation were measured using five-point Likert scale (Strong agree $=5$, Agree $=4$, undecided $=3$, Disagree $=2$, strongly Disagree $=1$ ) . However, this analysis supports that all constructs indicate discriminant validity and reliability of the study.

\section{DISCUSSION}

In chapter one, we first asked the question of what are the success factors for e-government policy innovation? Secondly, was to suggest the framework of egovernment policy innovation by integrating different levels of knowledge and strategic innovations. We explain how the developing countries (Tanzania, Rwanda, Kenya, and South Africa) can become a transporting vessel of e-government knowledge sharing and innovation focusing on e-government policy development (Koh et al., 2004; Kankanhalli et al., 2005). In making a national e-government policy innovation, it requires effective collaboration with developing country to facilitate knowledge sharing and innovation capabilities (Koh et al., 2004; Kankanhalli et al., 2005). Countries 
Table 2. The Principal Component Factor Analysis (Direct Oblimin) for E-government Policy Innovation Variables

\begin{tabular}{|c|c|c|c|c|c|c|}
\hline & \multicolumn{5}{|c|}{ Component } \\
\hline & & $\begin{array}{c}\text { Factor } \\
1\end{array}$ & $\begin{array}{c}\text { Factor } \\
2\end{array}$ & $\begin{array}{c}\text { Factor } \\
3\end{array}$ & $\begin{array}{c}\text { Factor } \\
4\end{array}$ & $\begin{array}{l}\text { Factor } \\
5\end{array}$ \\
\hline \multirow{6}{*}{$\begin{array}{l}\text { Coordinate knowledge } \\
\text { sharing on e-government } \\
\text { policies with nation and } \\
\text { international institutions }\end{array}$} & Local and foreign training on policy and IT & .965 & -.002 & .379 & .543 & .009 \\
\hline & New development on e-government & .963 & .032 & .377 & .570 & .024 \\
\hline & Online National information protection & .960 & .073 & .397 & .522 & .014 \\
\hline & $\begin{array}{l}\text { Coordinating the implementation of } \\
\text { e-government }\end{array}$ & .931 & .018 & .433 & .490 & -.063 \\
\hline & $\begin{array}{l}\text { Enhance internal training on e-government } \\
\text { policy }\end{array}$ & .833 & .059 & .490 & .412 & -.182 \\
\hline & Create a strong information architecture & -.046 & .861 & -.144 & -.116 & -.116 \\
\hline \multirow{5}{*}{$\begin{array}{l}\text { Empower and coordinate } \\
\text { e-government-think tank } \\
\text { forum locally and } \\
\text { nationally }\end{array}$} & $\begin{array}{l}\text { Encourage local online application for } \\
\text { communication }\end{array}$ & .096 & .835 & -.033 & .132 & -.265 \\
\hline & Forge ahead online protection institutionally & -.043 & .796 & -.172 & -231 & -.066 \\
\hline & Protect local data and information from attack & .109 & .762 & .058 & .219 & -351 \\
\hline & $\begin{array}{l}\text { Transform the government institutions to } \\
\text { e-government }\end{array}$ & -.017 & .753 & -.024 & .033 & .028 \\
\hline & $\begin{array}{l}\text { Share knowledge for national e-government } \\
\text { development }\end{array}$ & 129 & .741 & .104 & .012 & -.155 \\
\hline \multirow{6}{*}{$\begin{array}{l}\text { Create a technoculture } \\
\text { society at local and } \\
\text { national level }\end{array}$} & Bring society into one village & .445 & .047 & .903 & .354 & .059 \\
\hline & Become the leading center for e-government & .250 & -.090 & .885 & .254 & -.068 \\
\hline & Embrace the development of IT locally & .361 & -.131 & .855 & .247 & .039 \\
\hline & $\begin{array}{l}\text { Roll-out technology and support to local and } \\
\text { central government }\end{array}$ & .441 & .063 & .818 & .176 & .088 \\
\hline & Invest on institutional technology development & .372 & -.044 & .815 & .444 & -.032 \\
\hline & $\begin{array}{l}\text { Protect local knowledge by rewarding and } \\
\text { recognition }\end{array}$ & .410 & -.040 & .802 & .257 & .175 \\
\hline \multirow{5}{*}{$\begin{array}{l}\text { Develop and maintain } \\
\text { national information } \\
\text { enterprise architecture }\end{array}$} & $\begin{array}{l}\text { National information development standards } \\
\text { in place }\end{array}$ & .454 & .024 & .356 & .944 & .018 \\
\hline & Data codification and management in place & .617 & .092 & .372 & .935 & .013 \\
\hline & $\begin{array}{l}\text { Generally, IT systems are working and } \\
\text { up-to-date }\end{array}$ & .506 & -.050 & .294 & .934 & .076 \\
\hline & $\begin{array}{l}\text { Tailored IT training are conducted on a } \\
\text { weekly basis }\end{array}$ & .578 & .011 & .317 & .917 & .064 \\
\hline & $\begin{array}{l}\text { Absence of the institutional information } \\
\text { architecture }\end{array}$ & .537 & -169 & .521 & .578 & -.007 \\
\hline \multirow{2}{*}{$\begin{array}{l}\text { Support e-government } \\
\text { research alliance \& } \\
\text { engagement }\end{array}$} & $\begin{array}{l}\text { Conduct national forums on national } \\
\text { e-government development program }\end{array}$ & .306 & -.081 & .384 & .242 & .708 \\
\hline & $\begin{array}{l}\text { Conduct institutional competition with social } \\
\text { network group, private and entrepreneurship } \\
\text { group }\end{array}$ & .328 & .230 & .211 & .089 & -679 \\
\hline
\end{tabular}

Extraction Method: Principal Component Analysis.

Rotation Method: Oblimin with Kaiser Normalization. 
within countries will acquire significant knowledge to develop regional e-government policy for future utilization.

\section{Success Factors for E-Government Policy Innovation}

Regarding the first question, our results found four factors which are important and connected direct to collaboration within developing countries towards e-government policy innovation: Coordinate knowledge sharing on e-government policies with nation and international institutions; Empower and coordinate e-government-think tank forum locally and nationally; create techno-culture society at local and national level; and Support e-government research alliance \& engagement (Table 3).

The analysis from developing countries such as Rwanda suggests that the e-government policy innovation was initiated to address issues of access to ICT, training and capacity building, e-government and mGovernment applications. In comparison to the current analysis in this study, it suggests that Rwandan case was driven by a talented pool of technicians combined with their government institution's expertise to develop e-government policy innovation. While in Kenyan case, was through the establishment of techno-centers, Kenyan education network (KENET) geared to collaboration, digital villages, ICT knowledge at the local and national level, the KONZA technology park, and the IST-Africa research. In comparison with the study results, this suggests that Kenyan e-government policy innovation was influenced by knowledge and innovation from the different networked group, government interventions, and effective change within institutional structures. Finally, the case of South Africa, they developed a 10

Table 3. Mean Score for E-government Policy Innovation

\begin{tabular}{l|c|c|c|c|c}
\hline Variables & Observation & Mean & $\begin{array}{c}\text { Standard } \\
\text { Deviation }\end{array}$ & Minimum & Maximum \\
\hline $\begin{array}{c}\text { F1: Coordinate knowledge sharing on } \\
\text { e-government policies with nation } \\
\text { and international institutions }\end{array}$ & 87 & 3.2184 & 1.19597 & 1.00 & 5.00 \\
\hline $\begin{array}{c}\text { F2: Empower and coordinate } \\
\text { e-government-think tank forum } \\
\text { locally and nationally }\end{array}$ & 87 & 3.5498 & 1.11893 & 1.00 & 5.00 \\
\hline $\begin{array}{c}\text { F3: Create a technoculture society } \\
\text { at local and national level }\end{array}$ & 87 & 2.8713 & 1.05697 & 1.00 & 5.00 \\
\hline $\begin{array}{c}\text { F4: Support e-government research } \\
\text { alliance \& engagement }\end{array}$ & 87 & 3.5172 & .86080 & 1.00 & 5.00 \\
\hline
\end{tabular}

Table 3 shows the summated mean score and standard deviation computed to show the correlations among the items. 
years e-government plan. They had established presidential national councils on ICT to foresee the development of e-government policy innovation. Compared to the results from the current study, suggests that e-government policy is significantly influenced by knowledge and innovation. Whereas, the institutional e-government knowledge is statistically influenced by e-government research alliance \& engagement on one hand and the technoculture society on the other hand. The results on which can speed up the development of e-government policy innovation through its national e-governmentthink tank as an institution.

According to the results analysis in Table 3, indicate the highest mean score and standard deviation among items. In developing the study presents, government institutions challenges from poor institutional setup, governance structure, weak leadership, lack of knowledge, financial resources, to technical infrastructure. The study found that the fundamental sources for all these challenges are the lack of knowledge and innovation in e-government policy.

\section{The Framework of E-Government Policy Innovation}

Figure 1 and the results in Table 3 presents the framework for e-government policy innovation. In comparison with the case study this results shows that empowering and coordinating e-government-think tank forum locally and nationally with a mean score value of $(M=3.55 ; S D=1.12)$ is the key driver for enhancing institutional knowledge sharing to address these challenges through designing and enacting the e-government policy innovation (Lin, 2008). In comparison with knowledge sharing with mean score $(M=3.218 ; S D=1.19)$ suggests that Collaboration within the developing country ${ }^{4}$ would facilitate speedy knowledge recovery and innovation by changing governance structure in order to empower national e-government-think tank. The national e-government-think tank needs support in terms of learning, network e-government research with developing country, collaboration and joint innovation are more significant. This is followed by supporting e-government research alliance and encourage engagement among countries and has a mean value score of $(M=3.51 ; S D=0.86)$. in comparison with e-government-think tank scored a mean value $(M=3.54 ; S D=1.11)$ suggests that For government institutions to prosper it requires external support and collaboration (within the developing country) on the basis of developing research on e-government policy. This is an important factor for enhancing local and national knowledge sharing on e-government as the most strategic innovation to influence institutional setup, governance structure, technical and IT infrastructure through implementing e-government

4. $\mathrm{DC}=$ Developing Countries such as Rwanda, Kenya, and South Africa. 
policy (Kankanhalli et al., 2005).

This analysis is consistent with the previous research which suggests that the government institutional should strongly support and coordinate the e-government-think tank locally and externally (within the developing country) in order to accumulate and share knowledge (Nonaka, 1994; Krogh \& Nonaka, 2000). Our results show an increased level of e-government innovation as well as improve the e-government policy innovation development (Table 3 and Table 4) depends on strong networking and collaboration within the developing country (Kankanhalli et al., 2005). However, government institution should strengthen the creation and setup of the national institution technoculture society within Tanzania. In comparison with our analysis this support the above idea by a mean score value $(M=2.87 ; S D=1.06)$, emphasizing on multiplying the expansion of e-government knowledge through creating and developing labs and centers for future e-government innovation.

Previous literature shows that knowledge sharing on e-government policy with an engagement of national and international institutions within the developing country (Nonaka, 1994; Krogh \& Nonaka, 2000; Lin, 2008) shows as an important factor loading with a mean score value of $(M=3.21 ; S D=1.20)$. This explains that, the factor has much to offer in enhancing the nation's capability and competitiveness in terms of e-government knowledge, experiences, financial resources, leadership as well as technical infrastructure (Nonaka and Takauchi, 1995; Babu et al., (2007c). Knowledge sharing has been regarded as critical resources not only for organization's but also for nation's capability in terms of implementing policies for effective transformation of technologies or e-government project (Nonaka, 1994; Krogh \& Nonaka, 2000).

The above table 4 indicates the correlations between variables extracted from each construct. Regarding our research question, the results shows, on average, there is evidence $(\mathrm{p}<0.01$, respectively) that multiple innovations outside the government

Table 4. Correlation among the Constructs

\begin{tabular}{|c|c|c|c|c|}
\hline & $\mathrm{F} 1$ & $\mathrm{~F} 2$ & F3 & $\mathrm{F} 4$ \\
\hline $\begin{array}{l}\text { F1: Coordinate knowledge sharing on e-government } \\
\text { policies with nation and international institutions }\end{array}$ & 1 & & & \\
\hline $\begin{array}{l}\text { F2: Empower and coordinate e-government-think } \\
\text { tank forum locally and nationally }\end{array}$ & $.643^{\star \star}$ & 1 & & \\
\hline $\begin{array}{l}\text { F3: Create an techno-culture society at local and } \\
\text { national level }\end{array}$ & $.677^{\star \star}$ & $.520^{\star *}$ & 1 & \\
\hline $\begin{array}{l}\text { F4: Support e-government research alliance \& } \\
\text { engagement }\end{array}$ & $.486^{\star \star}$ & $.470^{\star *}$ & $.330^{\star *}$ & 1 \\
\hline
\end{tabular}


institutions are the critical and fundamental base for e-government policy innovation development. These multiple innovations involve collaboration, institutional innovation and resources and their linkages to e-government knowledge creation $(\mathrm{p}<0.01$, respectively) within the developing country is indeed crucial. Creating techno-culture society is positively correlated with empowering and coordinate e-government think tank $(\mathrm{p}<0.01$, respectively) where this multiple knowledge does exist within the developing country.

However, figure 1 shows e-government knowledge that impact of technoculture across the nation (internalization) and within the developing country (externalization) is correlated with the e-government think tank (socialization) forum at a local and national level (Nonaka, 1994). These results explain that e-government thinks tank, from local and nations are important factors as combinative (Kogut \& Zander, 1992, p. 391; Kankanhalli et al., 2005) knowledge to bring good governance structure, new institutional setup as well as strengthen leadership within the developing countries. This knowledge can be shared to develop future e-government policy innovation $(\mathrm{p}<0.01$, respectively). Furthermore, in comparison with e-government research alliance and engagement at different levels that involves the developing countries (DC) is positively correlated with technoculture society, the e-government thinks tank forum as well as the knowledge sharing on e-government policies with national and international institutions. Overall the analysis shows that knowledge sharing is the source of innovation that strictly requires socialization, combination, internalization and externalization (Nonaka, 1994; Koh et al., 2004; Kankanhalli et al., 2005) of networking within the developing countries (DC). Effective national e-government policy innovation development would only happen when "serious" interaction and engagement in e-government research and development is obvious. Therefore, coordination, support and the development of e-government research alliance and engagement, techno-culture society and empower e-government to think tank forum is positively significant $(\mathrm{p}<0.01$, respectively) as the key driver to the success of national e-government policy innovation (Figure 1).

\section{CONCLUSION AND IMPLICATION}

The advancement of technology and the demand for e-government transformation in Tanzania is steadily escalating leaving challenges such as lack of knowledge, financial resources, technical infrastructure, governance structure, institutional setup and so forth and are demanding the government institutions to respond to it. One way they can do is through collaboration and networking within the developing countries (DC). This 
would force the government institutions to plan and develop first class knowledge creation and management systems with a strong database of innovation targeting for the future innovation in e-government policy (Metcalfe et al., 1998; Kankanhalli et al., 2005).

One way to do that is, government institutions should empower and create an institutional working culture, staff attitudes, and provide motivation for enhancing knowledge sharing at a national level. The study recommends that top management should support and encourage knowledge creation and innovation through research and publications within the developing country. However, they can encourage their staff member for participating and organizing national and international forums or conferences on egovernment policy innovation around DC. This way would help government institutions to intensify the dissemination of knowledge via various methods.

While government institutions understand that knowledge sharing is as "natural activities" of government staff and other institutions within and outside the country. Therefore, policy makers as an institution should form a roadmap for collaboration and networking by forming ties with e-government institutions policy innovation internally and externally. This would support easily the future e-government policy innovation and development in Tanzania. They can use various opportunities such as seminars, conferences, and publication from locally, nationally and goes up to another developing country. This may provide eagerness of government and private institutions to share knowledge and encourage policy innovation development. Government institutions should establish a policy direction that encourages its institutions for more rigorous e-government researchers across local vs central government; academic institutions; private institutions; social networking group; ICT or other professional bodies' e-think tank in collaboration with the developing country. It should encourage and establish centers such as e-government kiosk in each region across Tanzania by learning from another developing country. This would escalate the knowledge sharing and encourage innovation on e-government policy. In the end, government institution's knowledge will be produced, integrated and shared within local and central government institutions for the betterment of future national e-government policy innovation and effective transformation.

\section{LIMITATION AND FUTURE RESEARCH WORK}

The general election campaign in Tanzania was a limitation to this study. Some participants' private institutions, social forum institutions, and entrepreneurship were participating in the general election campaign. It was difficult to get results on time 
and, therefore, spending more time investigating their whereabouts. For instance, the number of respondents was 112 , but due to the general election campaign has affected the response rate to 87 . This was a limitation of the survey.

Developing countries such as Tanzania is struggling to develop a sustainable framework for e-government policy innovation. We believe that the provided cutting age framework for e-government knowledge creation as a source of innovation in the development of e-government policy is not the means to an end. Therefore, future research work should focus on empirically analyze this framework to see how institutional abilities can apply this framework as an opportunity for innovation in e-government policy. Another area to consider is to analyze these factors and show the visibility implementation roadmap at local and national level.

\section{REFERENCES:-}

Alexander L. George. 1980. Presidential decision-making in foreign policy: The effective use of information and advice by. Boulder, Colo., Westview Press.

Arcot, Sridhar R., \& Bruno, Valentina Giulia. 2006. One size does not fit all, after all: Evidence from corporate governance (working paper). Retrieved on July 18, 2015, from http://ssrn.com/abstract $=887947$.

Babu, Suri, G., K. S. Gupta, \& S. Ahmed. 2007c. Leadership capability and knowledge management success: Framework. Paper presented at the UGC Sponsored National Seminar on High Performance organizations and Knowledge Management, SIBER, Kolhapur, 5-7, March 2007.

Bagozzi, R. P., \& Yi, Y. 1988. On the evaluation of structural equation models. Academic of Marketing Science, 16(1).

Berry, F., \& Berry, W. 1990. State lottery adoption as policy innovation: An event history analysis. The American Political Science Review, 84(2): 395-415.

Bierly, P., \& Daly, P. 2002. Aligning human resource management practices and knowledge strategies. In Choo, C., \& Bontis, N. (eds.), The strategic management of intellectual capital and organizational knowledge (pp. 277-295). Oxford University Press, New York, NY.

Bollinger, A. S., \& Smith, R. D. 2001. Managing organizational knowledge as a strategic asset. Journal of Knowledge Management, 5(1): 8-18.

Bommert, B. 2010. Collaborative innovation in the public sector. International Public Management Review, 11(1): 15-33.

Cabrera, E. F., \& Cabrera, A. 2005. Fostering knowledge sharing through people management practices. International Journal of Human Resource Management, 
16(5): 720-735.

Chen, C-J., \& Huang, J-W. 2009. Strategic human resource practices and innovation performance: The mediating role of knowledge management capacity. Journal of Business Research, 62: 104-114.

Choi, B., \& Lee, J. -N. 2012. Complementarities and substitutabilities among knowledge sourcing strategies and their impact on firm performance. Journal of the Association for Information Systems, 13(7): 498-545.

Choi, T. Y., \& Hartley, J. L. 1996. An exploration of supplier selection practices across the supply chain. Journal of Operations Management, 14: 333-343.

Dalkir K. 2011. Knowledge management in theory and practice (2nd ed.). Boston: Massachusetts Institute of Technology.

Davenport, T. H., \& Prusak, L. 1998. Information ecology: Mastering the information and knowledge environment. New York: Oxford University Press.

Donate, M. J., \& Guadamillas, F. 2010. The effect of organizational culture on knowledge management practices and innovation. Knowledge and Process Management, 17(2): 82-94.

Earl, M. 2001. Knowledge management strategies: Toward a taxonomy. Journal of Management Information Systems, 18(1): 215-233.

Edna P, Tuvya R. 2011. The complete guide to knowledge management: A strategic plan to leverage your company's intellectual capital. New York: Wiley.

Fountain, J. E. 2001. Building the virtual state: Information technology and institutional change (pp. 155-189). Washington, D.C.: Brookings Institution Press.

Garavelli, C., Gorgoglione, M., \& Scozzi, B. 2004. Knowledge management strategy and organization: A perspective of analysis. Knowledge and Process Management, 11(4): 273-282.

Grant R. M. 1996. Toward a knowledge based theory of the firm. Strategic Management Journal, 17(1): 109-122.

Grant, M. R. 1996a. Prospering in dynamically-competitive environments: Organizational capability as knowledge integration. Organization Science, 7(4): 375-387.

Grant, M. R. 1996b. Toward a knowledge-based theory of the firm. Strategic Management Journal, 17(Winter): 109-122.

Grant, R. M. 2002. Contemporary strategy analysis: Concepts, techniques, and applications (4th ed.). Boston, MA: Blackwell Publishers.

Grant, Robert. 1991. The resource-based theory of competitive advantage: Implications for strategy formulation. California Management Review, 33(3): 114-135.

Gray, V. 1973. Innovation in the states: A diffusion study. The American Political Science Review, 67(4): 1174-1185.

Hargadon, A. B. 1998. Firms as knowledge brokers: Lessons in pursuing continuous 
innovation. California Management Review, 40(3): 209-227.

Heeks, R. 2003a. Most e-government-for-development projects fail: How can risks be reduced? Institute for Development Policy and Management, University of Manchester.

Heeks, R. 2006. Understanding and measuring e-government: International benchmarking studies. Manchester, UK: University of Manchester. Retrieved on Julay 1, 2015, from http://unpan1.un.org/intradoc/groups/public/documents/UN/UNPAN0236 86.pdf.

Heeks, R. 2006a. Implementing and managing e-government. London: Sage Publications Ltd.

Heeks, R. 2008. Success and failure in e-government projects. eGov4Dev. Retrieved on August 1, 2015, from http://www.egov4dev.org/success/index.shtml.

Heeks, R. (ed.). 1999. Reinventing government in the information age: International practice in IT enabled public sector reform. London: Routledge.

Heeks, R. 2000. Reinventing government in the information age. In L. Klamo, W. W., Huang, K. L. Wang, \& T. Le (eds.), Successfully implementing egovernment: Fundamental issues and a case study in the USA, 2006 (pp. 158-173). London: Electronic Government, Roultedge Press.

Heeks, R., \& Kenny, C. 2002. ICTs and development. In Krishna, S., \& Madon, S. (eds.), Proceedings of the 7th international working conference of IFIP WG9.4: New opportunities, perspectives, and challenges. India: Bangalore.

Jain, K. K., Sandhu, M. S., \& Sidhu, G. K. 2007. Knowledge sharing among academic staff: A case study of business schools in Klang Valley. Malaysia. JASA, 2, 2329.

Jantunen, A. 2005. Knowledge-processing capabilities and innovative performance: An empirical study. European Journal of Innovation Management, 8(3): 336-349.

Kankanhalli A, Tan B. C. Y., \& Wei K. K. 2005. Contributing knowledge to electronic knowledge respositories: An empirical investigation. MIS Quarterly, 29(1): $113 \mathrm{e} 45$.

Kogut, B., \& Zander, U. 1992. Knowledge of the firm, combinative capabilities, and the replication of technology. Organization Science, 3(3): 383-397.

Kogut, B., \& Zander, U. 1993. Knowledge of the firm and the evolutionary theory of the multinational corporation. Journal of International Business Studies, 24(4): 625-645.

Kogut, B., \& Chang, S. J. 1991. Technological capabilities and Japanese foreign direct investment in the United States. Rev. Econ. Stat., 73: 401-413.

Koh, J., \& Kim, Y. G. 2004. Knowledge sharing in virtual communities: An e-business perspective. Expert Systems with Applications, 26(2): 155-166. 
Kotabe, M., Dunlap-Hinkler, D., Parente, R., \& Mishra, H. A. 2007. Determinants of cross-national knowledge transfer and its effect on firm innovation. J. Int. Bus. Stud. 38(2): 259-282.

Krogh G., Ichijo K., \& Nonaka I. 2000. Enabling knowledge creation: How to unlock the mystery of tacit knowledge and release the power of innovation. Oxford: Oxford University Press.

Lee, H., \& Choi, B. 2003. Knowledge management enablers, processes, and organizational performance: An integrative view and empirical examination. Journal of Management Information Systems, 20(1): 179-228.

Lee, J. H., Kim, Y. G., \& Kim, M. Y. 2006. Effects of managerial drivers and climate maturity on knowledge-management performance: Empirical validation. Information Resources Management Journal, 19(3): 48-60.

Leiponen, A., \& Helfat, E. C. 2011. Location, decentralization, and knowledge sources for innovation. Organization Science, 22(3): 641-658.

Lichtenthaler, U. 2009. Absorptive capacity, environmental turbulence, and the complementary of organizational learning process. Academy of Management Journal, 52(4): 822-846.

Liebowitz, J. 2002. Facilitating innovation through knowledge sharing: A look at the U.S. naval surface warfare center-carderock division. Journal of Computer Information Systems, 42(5): 1-6.

Lin, B.-W., \& Wu, C.-H. 2010. How does knowledge depth moderate the performance of internal and external knowledge sourcing strategies? Technovation, 30: 582589.

Lin, H. F. 2006. Impact of organizational support on organizational intention to facilitate knowledge sharing. Knowledge Management Research and Practice, 4(1): 26-35.

Lin, H. F., \& Lee, G. G. 2004. Perceptions of senior managers toward knowledgesharing behaviour. Management Decision, 42(1): 108-125.

Lin, H. F., \& Lee, G. G. 2006. Effects of socio-technical factors on organizational intention to encourage knowledge sharing. Management Decision, 44(1): 74-88.

Lin, W. B. 2008. The effect of knowledge sharing model. Expert Syst, 34(2): 10-21.

Lloyd-Reason, L., K. Muller, \& S. Wall. 2002. Innovation and education policy in SMEs: A Czech perspective. Education Plus Training, 44(8/9): 378-387.

Lupilya, E., \& Jung, K. 2015. E-government transformation in Tanzania: Status, opportunities, and challenges. The Korean Journal of Policy and Studies, 30(1): 147-184.

Lupilya, E. 2015. E-government strategic plan implementation in Tanzania: Learning from challenges and experiences from Kenya, Korea, India, and Malaysia. The Korean Journal of Policy and Studies, 30(2): 147-175. 
Maumbe, B. M., \& Owei, V. T. 2007. E-government policy development in South Africa: Current status, distributional issues, and future prospects. In proceedings of the IST-Africa Conference, May 9-11. Maputo Mozambique.

McLendon, M., Heller, D., \& Young, S. 2005. State postsecondary policy innovation: Politics, competition, and the interstate migration of policy ideas. The Journal of Higher Education, 76(4): 363-400.

Metcalfe, S., \& N. De Liso. 1998. Innovation, capabilities and knowledge: The epistemic connection. In R. Coombs et al. (eds.), Technological change and organization (pp. 8-27). Edward Elgar Publishing.

Mintrom, Michael. 1997. Policy entrepreneurs and the diffusion of innovations. American Journal of Political Science, 41(3): 738-770.

Mohr, Lawrence B. 1969. Determinants of innovation in organizations. American Political Science Review, 75: 963-974.

Mutula S. M., \& Mostert J. 2010. Challenges and opportunities of e-government in South Africa. The Electronic Library, 28(1): 38-53.

Ndou, V. 2004. E-government for developing countries: Opportunities and challenges. The Electronic Journal of Information Systems in Developing Countries, 18(1): 1-24.

Nonaka, I. 1991. The knowledge creating company. Harvard Business Review, November-December: 96-104.

Nonaka, I. 1994. A dynamic theory of organizational knowledge creation. Organization Science, 5(1): 14-37.

Nonaka, I., \& Takeuchi, H. 1995. The knowledge creating company: How Japanese companies create the dynamics of innovation. New York, NY: Oxford University Press.

Nonaka, I., \& D. Senoo. 1996. From information processing to knowledge creation: A paradigm shift in business management. Tech. Soc., 18(2): 203-218.

Nunnally, J. C., \& Bernstein, I. H. 1994. Psychometric theory (3rd ed.). New York: McGraw-Hill.

Rabaiah, A., \& Vandijck, E. 2009. A strategic framework of e-government: Generic and best practice. Electronic Journal of e-Government, 7(3): 241-258.

Rogers, E. 1983. Diffusion of innovations. New York: Free Press.

Skyrme, D. 2002. Knowledge management: Approaches and policies. Knowledge Management.

Sohail, S. M, \& Salina Daud. 2009. Knowledge sharing in higher education institutions: Perspectives from Malaysia. VINE, 39(2): 125-142.

Song, S. 2002. An internet knowledge sharing system. Journal of Computer Information Systems, 42(3): 25-30. 
Sørensen, E., \& J. Torfing. 2011. Enhancing collaborative innovation in the public sector. Administration and Society, 43(8): 842-868.

Streiner D. L., \& Norman G. R. 1995. Health measurement scales: A practical guide to their development and use (2nd ed.). Oxford Medical Publications, Inc.

TFPL. 1999. Skills for knowledge management: Building a knowledge economy. London: TFPL. Retrieved on August 1, 2015, from http://www.lic.gov.uk/publications/ executivesummaries/kmskills.pdf.

Thandika, M. 2009. Institutional monocropping and monotasking in Africa. Geneva, Switzerland: United Nations Research institute for Social Development.

UNESCO. 2005. E-government toolkit for developing countries. New Delhi: UNESCO. Retrieved on August 11, 2015, from http://unesdoc.unesco.org/images/0013/ 001394/139418e.pdf.

United Nations. 2012. United Nations e-government survey 2012: E-government for the people. Retrieved on Septermber 1, 2015, from http://unpan1.un.org/intradoc/ groups/public/documents/un/unpan048065.pdf.

URT. 2003. Tanzania ICT policy. President's office: Public service management. Tanzania: Dar es Salaam.

URT. 2012. Tanzania e-government strategy. President's office: Public service management. Tanzania: Dar es Salaam.

Walker, J. 1969. The diffusion of innovations among the American states. The American Political Science Review, 63(3): 880-899.

Yeh, Y. J., Lai S. Q., \& Ho C. T. 2006. Knowledge management enablers: A case study. Indust Manag Data Syst, 106(6): 793e810.

Zack, M., McKeen, J., \& Singh, S. 2009. Knowledge management and organizational performance: An exploratory survey. Journal of Knowledge Management, 13(6): 392-409.

Zelikow, Philip. 1994. Foreign policy engineering: From theory to practice and back again. International Security, 18(4): 143-171. 
Appendix 1. Total Variance Explained

\begin{tabular}{c|c|c|c|c|c|c|c}
\hline \multirow{2}{*}{ Component } & \multicolumn{3}{|c|}{ Initial Eigenvalues } & \multicolumn{3}{c|}{$\begin{array}{c}\text { Extraction Sums of Squared } \\
\text { Loadings }\end{array}$} & $\begin{array}{c}\text { Rotation Sums of } \\
\text { Squared Loadings }\end{array}$ \\
\cline { 2 - 8 } & Total & $\begin{array}{c}\% \text { of } \\
\text { Variance }\end{array}$ & $\begin{array}{c}\text { Cumulative } \\
\%\end{array}$ & Total & $\begin{array}{c}\% \text { of } \\
\text { Variance }\end{array}$ & $\begin{array}{c}\text { Cumulative } \\
\%\end{array}$ & Total \\
\hline 1 & 10.262 & 42.757 & 42.757 & 10.262 & 42.757 & 42.757 & 7.349 \\
\hline 2 & 4.125 & 17.187 & 59.944 & 4.125 & 17.187 & 59.944 & 3.394 \\
\hline 3 & 2.299 & 9.580 & 69.524 & 2.299 & 9.580 & 69.524 & 6.886 \\
\hline 4 & 1.422 & 5.926 & 75.450 & 1.422 & 5.926 & 75.450 & 7.338 \\
\hline 5 & 1.093 & 4.556 & 80.007 & 1.093 & 4.556 & 80.007 & 2.822 \\
\hline 6 & .952 & 3.967 & 83.973 & & & & \\
\hline 7 & .841 & 3.505 & 87.478 & & & & \\
\hline 8 & .582 & 2.426 & 89.904 & & & & \\
\hline 9 & .459 & 1.913 & 91.818 & & & & \\
\hline 10 & .388 & 1.616 & 93.433 & & & & \\
\hline 11 & .326 & 1.360 & 94.794 & & & & \\
\hline 12 & .302 & 1.258 & 96.052 & & & & \\
\hline 13 & .208 & .868 & 96.920 & & & & \\
\hline 14 & .190 & .791 & 97.711 & & & & \\
\hline 15 & .180 & .751 & 98.462 & & & & \\
\hline 16 & .104 & .435 & 98.897 & & & & \\
\hline 17 & .086 & .360 & 99.256 & & & & \\
\hline 18 & .059 & .246 & 99.502 & & & & \\
\hline 19 & .046 & .191 & 99.693 & & & & \\
\hline 20 & .028 & .118 & 99.811 & & & & \\
\hline 21 & .018 & .076 & 99.887 & & & & \\
\hline 22 & .013 & .056 & 99.943 & & & & \\
\hline 23 & .008 & .031 & 99.975 & & & & \\
\hline 24 & .006 & .025 & 100.000 & & & & \\
\hline
\end{tabular}

Extraction Method: Principal Component Analysis.

a. When components are correlated, sums of squared loadings cannot be added to obtain a total variance.

Appendix 2. The KMO and Bartlett's Test

\begin{tabular}{c|c|c}
\hline \multicolumn{2}{c|}{ Kaiser-Meyer-Olkin Measure of Sampling Adequacy. } & .773 \\
\hline \multirow{3}{*}{ Bartlett's Test of Sphericity } & Approx. Chi-Square & 2976.077 \\
\cline { 2 - 3 } & $\mathrm{df}$ & 276 \\
\cline { 2 - 3 } & Sig. & .000 \\
\hline
\end{tabular}

